RESIDENT

\& FELLOW

SECTION

Section Editor

Mitchell S.V. Elkind,

MD, MS

Brian L. Edlow, MD

Eli L. Diamond, MD, MPhil

Address correspondence and reprint requests to Dr. Brian L. Edlow, Brigham and Women's Hospital, Harvard Medical School, Department of Neurology, 75 Francis Street, Boston, MA 02115

bedlow@partners.org

\title{
Teaching NeuroImages: \\ Restricted diffusion in the corpus callosum after traumatic diffuse axonal injury
}

Figure Restricted diffusion associated with hemorrhagic diffuse axonal injury
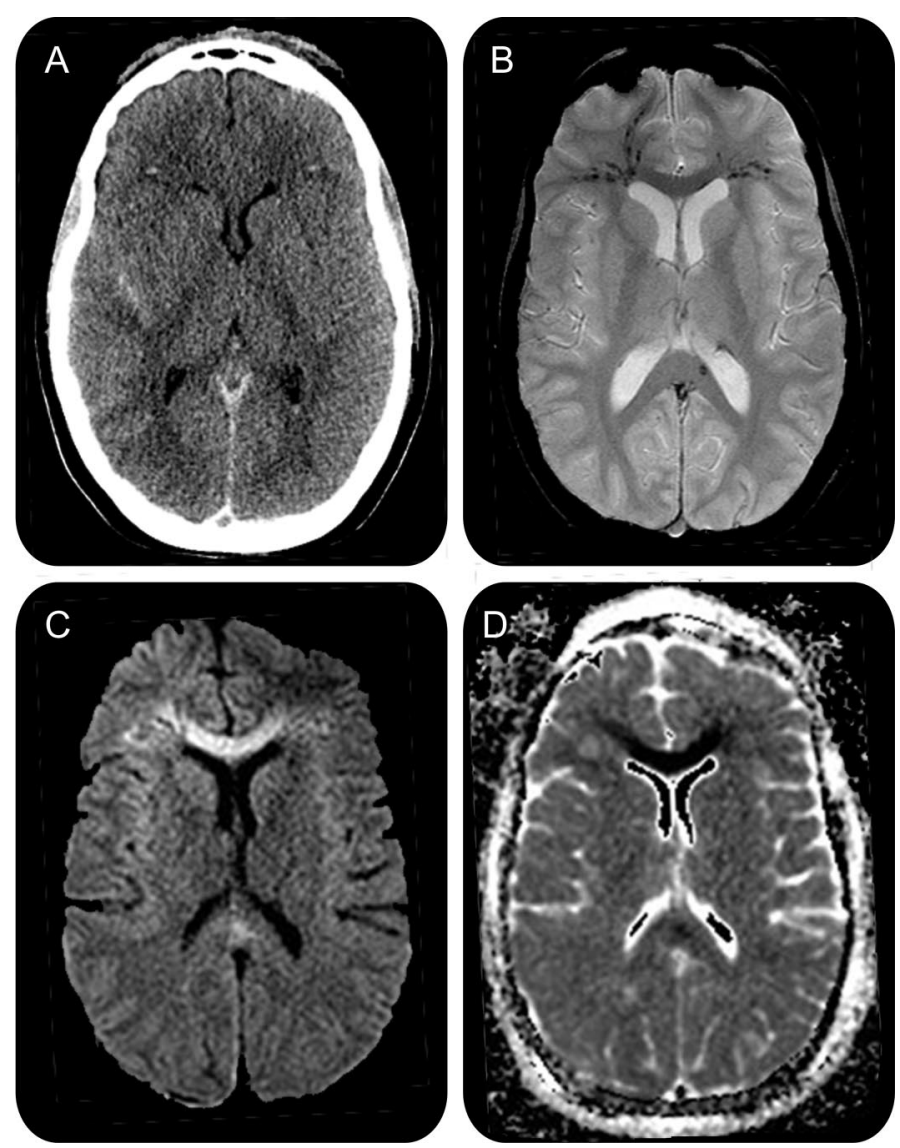

Bifrontal traumatic microbleeds (TMBs) are identified on head CT (A). Gradient-echo MRI (B) reveals additional TMBs involving the forceps minor fibers and the splenium of the corpus callosum. Diffusion-weighted MRI (C) and apparent diffusion coefficient map (D) demonstrate restricted diffusion in the genu of the corpus callosum extending into the bifrontal white matter.

A 19-year-old woman was hit by a car and found to be somnolent and inattentive on neurologic examination. Head CT demonstrated bifrontal traumatic microbleeds (figure), suggesting hemorrhagic diffuse axonal injury (DAI). MRI performed 7 days later showed extensive diffusion restriction in the genu of the corpus callosum. Follow-up MRI on day 27 confirmed resolution of these signal changes. The time course for diffusion restriction in DAI is variable, persisting up to 18 days post-trauma. ${ }^{1}$ Its pathogenesis has yet to be fully elucidated, with potential etiologies including swelling of sheared axons, Wallerian degeneration of interhemispheric neurons, and microvascular injury causing ischemia. ${ }^{2}$

\section{REFERENCES}

1. Liu AY, Maldjian JA, Bagley LJ, Sinson GP, Grossman RI. Traumatic brain injury: diffusion-weighted MR imaging findings. AM J Neuroradiol 1999;20:1636-1641.

2. Maxwell WL, Irvine A, Adams JH, Graham DI, Gennarelli TA. Response of cerebral microvasculature to brain injury. J Pathol 1988;155:327-335. 


\section{Neurology}

\section{Teaching NeuroImages: Restricted diffusion in the corpus callosum after traumatic diffuse axonal injury}

Brian L. Edlow and Eli L. Diamond

Neurology 2010;75;e69

DOI 10.1212/WNL.0b013e3181f962d7

This information is current as of October 25, 2010

\section{Updated Information \&} Services

References

Subspecialty Collections

Permissions \& Licensing

Reprints including high resolution figures, can be found at: http://n.neurology.org/content/75/17/e69.full

This article cites 2 articles, 1 of which you can access for free at: http://n.neurology.org/content/75/17/e69.full\#ref-list-1

This article, along with others on similar topics, appears in the following collection(s):

\section{Brain trauma}

http://n.neurology.org/cgi/collection/brain_trauma

DWI

http://n.neurology.org/cgi/collection/dwi

Intracerebral hemorrhage

http://n.neurology.org/cgi/collection/intracerebral_hemorrhage

MRI

http://n.neurology.org/cgi/collection/mri

Information about reproducing this article in parts (figures,tables) or in its entirety can be found online at:

http://www.neurology.org/about/about_the_journal\#permissions

Information about ordering reprints can be found online:

http://n.neurology.org/subscribers/advertise

Neurology ${ }^{\circledR}$ is the official journal of the American Academy of Neurology. Published continuously since 1951, it is now a weekly with 48 issues per year. Copyright Copyright (? 2010 by AAN Enterprises, Inc.. All rights reserved. Print ISSN: 0028-3878. Online ISSN: 1526-632X.

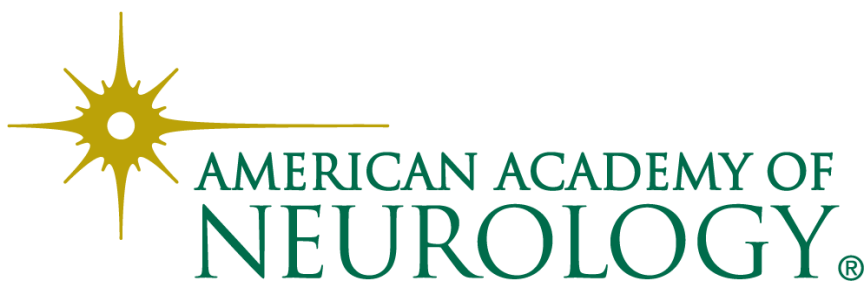

